\title{
Editorial
}

Journal of Innate

Immunity
J Innate Immun 2015;7:331-332

DOI: $10.1159 / 000430800$

\section{Foodies of Innate Immunity}

Elie Metchnikoff described phagocytosis as an active cellular process and suggested that it plays a role in host defense across a wide range of organisms [1]. He also suggested that macrophages play a role in the removal of senescent and damaged cells. Though Metchnikoff s findings were groundbreaking and still influence our current view of phagocytic processes, many novel and important aspects of phagocytosis have emerged in recent years. Our understanding of the complex roles of professional phagocytes, in addition to performing phagocytosis, has also increased [2]. In this issue of the Journal of Innate Immunity, Márkus et al. [3] demonstrate that a hitherto unrecognized cell type, called a multinucleated giant hemocyte, of a Drosophila species (see cover picture), encapsulates and kills parasites without melanization. Such cells are derived from the phagocytic cells of the sessile tissue and the circulation. Unexpectedly, it was found that they do not exhibit phagocytic activity, but rather fuse around their target. Multinucleated giant hemocytes are highly motile and share several features with mammalian multinucleated giant cells, a syncytium of macrophages formed during granulomatous inflammation. As observed in invertebrates, phagocytosis is also part of the conserved innate defense in early vertebrates. However, functional fine-tuning is achieved through specific cellbound receptors, such as the leukocyte immune-type receptor [4].

In humans, neutrophils are key players in host defense, executing several effector functions including phagocytosis, the production of reactive oxygen species, the release of cytotoxic granule proteins and the mobilization of neu- trophil extracellular traps $[5,6]$. In this issue, Carlsen et al. [7] demonstrate differential neutrophil responsiveness to distinct species of Leishmania amastigotes, the cause of cutaneous leishmaniasis in South America. Their findings suggest that different species possess specific mechanisms of resistance against neutrophil effector functions, and that this should be subject to further research. In another study, Braem et al. [8] show that neutrophil killing of the important fungal pathogen Aspergilus fumigatus is dependent on complement rather than specific antibodies. This will have consequences with respect to future therapeutic strategies, not least for vaccination.

Macrophages can regulate inflammation, but a janitorial function is also important, for example, the removal of apoptotic cells (efferocytosis) [9-11]. In this context, autophagy, involving the recycling of cells and debris, plays a critical role [12-15]. This is not least important in the ageing immune system where it can prevent excess inflammation [16]. Autophagy is also a key process in host defense against viral infection, orchestrating pathogen degradation (xenophagy), innate immune signaling and certain aspects of adaptive immunity [17]. In human disease, it can play a fundamental role, as demonstrated in Crohn's disease [18].

Our understanding of the general mechanisms involved in the 'eating' and what to 'eat' processes of phagocytosis is rapidly increasing. This is also an area where novel therapeutic strategies to treat common diseases, such as infectious diseases, are likely to emerge.

Heiko Herwald, Lund Arne Egesten, Lund 


\section{References}

$>1$ Gordon S: 'Elie Metchnikoff: father of natural immunity’. Eur J Immunol 2008;38:32573264.

$>2$ Mills CD, Ley K: M1 and M2 macrophages: the chicken and the egg of immunity. J Innate Immun 2014;6:716-726.

3 Márkus R, Lerner Z, Honti V, Csordás G, Zsámboki J, Cinege G, Párducz Á, Lukacsovich T, Kurucz É, Andó I: Multinucleated giant hemocytes are effector cells in cell-mediated immune responses of Drosophila. J Innate Immun 2015;7:340-353.

$\checkmark 4$ Cortes HD, Lillico DME, Zwozdesky MA, Pemberton JG, O’Brien A, Montgomery BCS, Wiersma L, Chang JP, Stafford JL: Induction of phagocytosis and intracellular signaling by an inhibitory channel catfish leukocyte immune-type receptor: evidence for immunoregulatory receptor functional plasticity in teleosts. J Innate Immun 2014;6:435-455.

5 Nauseef WM, Borregaard N: Neutrophils at work. Nat Immunol 2014;15:602-611.

-6 Lu T, Porter AR, Kennedy AD, Kobayashi SD, DeLeo FR: Phagocytosis and killing of Staphylococcus aureus by human neutrophils. J Innate Immun 2014;6:639-649.
7 Carlsen ED, Jie Z, Liang Y, Henard CA, Hay C, Sun J, de Matos Guedes H, Soong L: Interactions between neutrophils and Leishmania braziliensis amastigotes facilitate cell activation and parasite clearance. J Innate Immun 2015;7:354-363.

$\checkmark 8$ Braem SGE, Rooijakkers SHM, van Kessel KPM, de Cock H, Wösten HAB, van Strijp JAG, Haas P-JA: Effective neutrophil phagocytosis of Aspergillus fumigatus is mediated by classical pathway complement activation. J Innate Immun 2015;7:364-374.

-9 Galvan MD, Hulsebus H, Heitker T, Zeng E, Bohlson SS: Complement protein $\mathrm{Clq}$ and adiponectin stimulate Mer tyrosine kinasedependent engulfment of apoptotic cells through a shared pathway. J Innate Immun 2014;6:780-792.

10 Verneret M, Tacnet-Delorme P, Osman R, Awad R, Grichine A, Kleman JP, Frachet P: Relative Contribution of $\mathrm{C1q}$ and apoptotic cell-surface calreticulin to macrophage phagocytosis. J Innate Immun 2014;6:426434.

11 Serafino A, Pica F, Andreola F, Gaziano R, Moroni N, Moroni G, Zonfrillo M, Pierimarchi P, Sinibaldi-Vallebona P, Garaci E: Thymosin $\alpha 1$ activates complement receptor-mediated phagocytosis in human monocyte-derived macrophages. J Innate Immun 2014;6: $72-88$.
2 Klionsky DJ, Codogno P: The mechanism and physiological function of macroautophagy. J Innate Immun 2013;5:427-433.

13 Moy RH, Cherry S: Antimicrobial autophagy: a conserved innate immune response in Drosophila. J Innate Immun 2013;5:444-455.

14 Faure M, Lafont F: Pathogen-induced autophagy signaling in innate immunity. J Innate Immun 2013;5:456-470.

15 Jiang S, Dupont N, Castillo EF, Deretic V: Secretory versus degradative autophagy: unconventional secretion of inflammatory mediators. J Innate Immun 2013;5:471-479.

16 Stranks AJ, Hansen AL, Panse I, Mortensen M, Ferguson DJP, Puleston DJ, Shenderov K, Watson AS, Veldhoen M, Phadwal K, Cerundolo V, Simon AK: Autophagy controls acquisition of aging features in macrophages. J Innate Immun 2015;7:375-391.

17 Dong X, Levine B: Autophagy and viruses: adversaries or allies? J Innate Immun 2013;5: 480-493.

18 Nguyen HT, Lapaquette P, Bringer MA, Darfeuille-Michaud A: Autophagy and Crohn's disease. J Innate Immun 2013;5:434-443. 